\title{
아프리카 개발을 위한 \\ 한국 이니셔티브에 대한 검토의견
}

'아프리카 개발을 위한 한국 이니셔티브' 에 대 한 탄자니아 대사관 검토의견을 아래 보고함.

\section{1. 총괄}

아프리카 빈곤퇴치 지원 강화를 위한 국제적 추 세에 동참하고 나아가 국제사회에서의 우리나라의 역할을 증대하려는 금번 아프리카 이니셔티브는 시의적절한 조치라고 사료되며, 조속한 시일 내에 보다 구체적이고 지속가능한 각국별 세부 이행계 획이 수립되기를 기대함.

\section{2. 사안별 검토내용}

\section{가. 대아프리카 ODA 확대 계획}

- 우리나라의 ODA 확대 계획과 관련, 대아프리 카 비중을 대폭 확대하려는 본부의 입장에 의 견을 같이 함. 다만 선진국의 경우 총 $\mathrm{ODA}$ 의 $36 \%$ 이상을 아프리카에 지원하고 있는 점과, 극심한 빈곤과 질병으로 시달리고 있는 아프리
카국가가 무려 53 개국에 달하는 점 등을 감안 할 때, 우리나라의 대아프리카 지원목표를 양 자간 무상원조의 $30 \%$ 이상으로 상향 조정할 필요가 있음.

- 또한 제한된 개발재원의 효과적 활용을 위해 선택과 집중의 전략이 필요한 바, 전 아프리카 국가를 대상으로 한 소규모의 동시다발적인 원 조 확대보다는, 최근의 경제발전 수준, 국가청 렴도 및 지역내 중추적 역할 등 다방면에서 아 프리카 모범국가로 성장하고 있는 일부 국가를 중점협력국가로 선정, 우선 확대 지원하고, 나 아가 인근국가 및 지역간 개발 효과로 이어지 는 소위 '점-선-면' 단계적 개발정책을 추진하 는 것이 필요.

- 나아가, 미국의 MCA(Millenium Challenge Account)와 유사한 원조체제를 도입하여 우리 의 원조철학 및 국별전략에 의한 평가기준을 설정, 동 기준에 부합하는 국가 위주로 중점 지 원하는 방안도 바람직하다고 사료됨. 
- 또한, 현행 대아프리카 무상원조는 연수생초 청, 전문가파견, 물자지원 등 소규모 기술협력 사업이 대부분인 바, 대폭 확대될 협력사업 이 행을 위해서는 중대형 프로젝트 및 개발조사사 업 위주로 사업형태를 전환할 필요가 있음.

\section{나. 우리나라의 개발 및 Good Governance}

\section{경험 공유}

- 우리나라의 개발경험 전수 및 향후 협력사업 확대를 모색코자 2005년 최초로 실시한 아프 리카 3 개국(남아공, 탄자니아, 르완다) 경제협 력세미나는 각국 정 - 재계의 높은 관심과 반향 을 불러일으키는 등 그 효과가 지대한 점을 감 안, 향후 경제세미나 실시국가 및 횟수의 점진 적 확대 필요.

- 국별연수 확대, 다양한 연수프로그램 개발

- 현행 소수 기술분야 연수와 병행하여 국별 특성 및 필요에 부합하는 국별연수프로그램 을 개발, 확대 실시하는 한편, 각국 주요 도 시 시장 또는 주지사 초청 등 다양한 프로그 램 추진 검토.

\section{다. 아프리카의 MDG 달성 지원}

\section{1) 농업분야}

- 농업분야 연구 - 개발지원 강화

- 우리나라의 대아프리카 농업분야 지원은 소 규모의 연수생초청, 전문가파견 및 물자지 원 위주로 실시되고 있어, 보다 체계적인 중 장기 농업개발전략 수립이 무엇보다도 절실
한 바, 아프리카 고유의 농업전략 수립을 위 한 연구 - 개발분야 지원 강화 필요.

- 예) 가칭 ‘농업기계화연구소 설립사업' 추진

아프리카 특유의 기후, 토질에 적합한 농기 계의 개발, 조립 및 생산이 가능한 농업기 계화 사업 추진 검토(현재 소강기에 접어든 우리나라 농기계업체 진출여건 마련)

2) 인적자원개발, 교육분야

- 청소년개발, 중고등학교 기초교육 지원 강화 필요

- 학교건립사업 및 교육분야 봉사단 확대파 견 추진

\section{라. 아프리카 지역기구, 국제기구와의 협력}

- 다양한 분야에서의 국제기구의 전문성을 활용 하기 위해 아프리카 지역기구 및 국제기구와의 협력사업 확대 필요

- 다만, 아프리카 전체기구와의 협력은 우리 $\mathrm{ODA}$ 사업규모에 비추어 시기상조일 것으로 사료되니 $\mathrm{EAC}, \mathrm{SADC}$ 등 주요 아프리카 지 역기구를 우선 Focal Point로 활용할 필요가 있으며, 이를 위해 이들 지역기구 및 주요 국 가와의 아프리카 원조공여국회의 및 개발협 력 정책대화(Policy Dialogue) 등을 확대 실 시(한-아세안 Dialogue 및 한-아세안 협력 사업 등 참조)

- 또한, 선진 원조기구(World Bank, USAID, JICA) 등과도 공동 협력사업(Joint Project) 추 진 검토 필요 


\section{마. 부채탕감 (EDCF 공여 등)}

- 아프리카국가를 대상으로 현행 EDCF 수혜국 조건의 대폭 완화 등 보다 많은 아프리카국가 들이 $\mathrm{EDCF}$ 를 활용할 수 있는 방안 강구 필요

\section{3. 기타 검토사항}

\section{가. 이니셔티브 중장기 이행계획수립 및 실행} 조직 확충

a 상기 아프리카 개발 이니셔티브에 의해 대폭 확대될 협력사업의 각국별 세부 이행계획 수립 및 안정적 추진을 위해, $\mathrm{KOICA}$ 및 수출입은행 해외사무소 등 전담인력 확충 필요

\section{나. 아프리카 지역연구 기능 및 현장중심의 조직} 강화

- 일본 JICA 아프리카지역본부(케냐) 등 선진 원 조기관들은 이미 수년 전부터 '지역본부제' 를 도입하여 지역 연구를 바탕으로 한 중장기 원 조계획 수립 및 지역내 인력 및 예산운용을 자 율적으로 실시하고 있는 등 현장 중심의 원조 수행체제를 갖추고 있는 바, 금번 아프리카 이 니셔티브를 계기로 보다 다양한 아프리카 지역 연구 지원 및 $\mathrm{KOICA}$ 아프리카 지역본부제 도 입 검토. 